\title{
Nitriding Process Characterization of Cold Worked AISI 304 and 316 Austenitic Stainless Steels
}

\author{
Waldemar Alfredo Monteiro, ${ }^{1}$ Silvio Andre Lima Pereira, ${ }^{2}$ and Jan Vatavuk $^{3}$ \\ ${ }^{1}$ Nuclear and Energy Research Institute, IPEN, Avenida Lineu Prestes 2242, 05508-000 São Paulo, SP, Brazil \\ ${ }^{2}$ MAHLE Metal Leve S/A, Rod. Anhanguera, s/n, Tijuco Preto, 13205-700 Jundiaí, SP, Brazil \\ ${ }^{3}$ School of Engineering, Presbyterian Mackenzie University, Rua da Consolação 930, 01302-901 São Paulo, SP, Brazil \\ Correspondence should be addressed to Waldemar Alfredo Monteiro; wamontei@ipen.br
}

Received 26 June 2016; Revised 9 September 2016; Accepted 18 September 2016; Published 18 January 2017

Academic Editor: Eric Jan Mittemeijer

Copyright (C) 2017 Waldemar Alfredo Monteiro et al. This is an open access article distributed under the Creative Commons Attribution License, which permits unrestricted use, distribution, and reproduction in any medium, provided the original work is properly cited.

\begin{abstract}
The nitriding behavior of austenitic stainless steels (AISI 304 and 316) was studied by different cold work degree (0\% (after heat treated), $10 \%, 20 \%, 30 \%$, and $40 \%$ ) before nitride processing. The microstructure, layer thickness, hardness, and chemical microcomposition were evaluated employing optical microscopy, Vickers hardness, and scanning electron microscopy techniques (WDS microanalysis). The initial cold work (previous plastic deformations) in both AISI 304 and 306 austenitic stainless steels does not show special influence in all applied nitriding kinetics (in layer thicknesses). The nitriding processes have formed two layers, one external layer formed by expanded austenite with high nitrogen content, followed by another thinner layer just below formed by expanded austenite with a high presence of carbon (back diffusion). An enhanced diffusion can be observed on AISI 304 steel comparing with AISI 316 steel (a nitrided layer thicker can be noticed in the AISI 304 steel). The mechanical strength of both steels after nitriding processes reveals significant hardness values, almost $1100 \mathrm{HV}$, on the nitrided layers.
\end{abstract}

\section{Introduction}

The austenitic stainless steels are plenty utilized in chemical processes equipment in pharmaceutical, foodstuff, textile, petroleum, and cellulose industries, where these components are exposed at aggressive ambient conditions and low temperatures. These steels are also employed in orthopedic implant due to its biocompatibility [1].

The austenitic stainless steels, despite the elevated corrosion resistance, have low hardness that can only be partially improved by cold deformation reducing its application in components submitted to severe wear conditions [2-5].

To surpass this problem there are alternatives in the surface engineering to improve surface properties, without hindering all the other properties like the corrosion resistance. One alternative is the thermochemical heat treatment, the well-known nitriding process that basically can run by one of the three methods: gaseous, salt bath, or plasma. The nitride process, independent of the method, increases the superficial hardness of austenitic stainless steels and promotes higher wear resistance.

The literature has shown the possibility of austenitic stainless steels nitride processing, which is the occurrence of nitrogen in solid solution, increasing the hardness of the surface and the wear resistance without loss of corrosion resistance. FCC phase expanded by nitrogen atoms is obtained. This identification is relating to the obtained Xrays diffraction reflections that are dislocated with low Bragg angles relating to the positions in a normal austenite phase [6-13].

Gontijo et al. [8] mention that many literatures [7-13] define this phase formed at low temperature as a nitrogen supersaturate phase, with a distorted crystalline structure (tetragonal structure). The plasma nitriding permits the introduction of nitrogen in steels with temperatures as low as $450^{\circ} \mathrm{C}$, producing a harder structure and metastable phases resistant to the corrosion.

The austenitic stainless steels response to the conventional nitriding processes is surprising $\left(500^{\circ} \mathrm{C} \leq T \leq 600^{\circ} \mathrm{C}\right)$; 
TABLE 1: Chemical composition (weight\%) of the studied steels (NBR 5601:1981).

\begin{tabular}{lcccccccc}
\hline AISI & $\% \mathrm{C}$ & $\% \mathrm{Si}$ & $\% \mathrm{Mn}$ & $\% \mathrm{P}$ & $\% \mathrm{~S}$ & $\% \mathrm{Ni}$ & $\% \mathrm{Cr}$ & \% Mo \\
\hline 304 & 0.08 & 1.00 & 2.00 & 0.045 & 0.03 & $8.0 / 10.0$ & $18.0 / 20.0$ & $16.0 / 18.0$ \\
316 & 0.08 & 1.00 & 2.00 & 0.045 & 0.03 & $10.0 / 14.0$ & $2.0 / 3.0$ \\
\hline
\end{tabular}

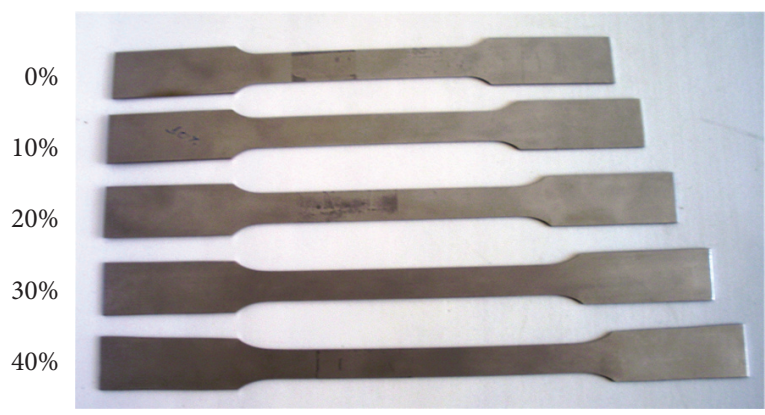

(a)

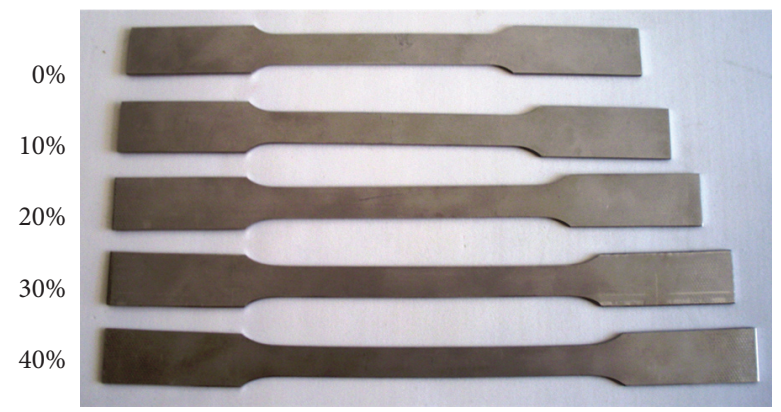

(b)

FIGURE 1: Nondeformed and deformed samples: (a) AISI 304 and (b) AISI 316.

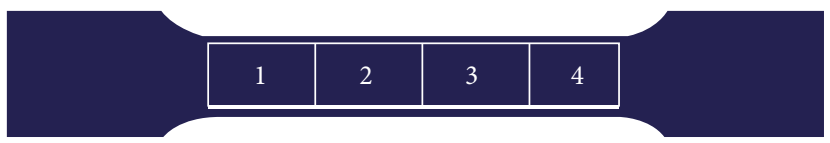

FIGURE 2: Schema of distribution of each divided sample.

a metal initially with hardness of $200 \mathrm{HV}$ can surpass values of $1300 \mathrm{HV}$ in the nitriding layer, very close to some carbides tool steels carbides. Singer was the first author to identify this layer as expanded austenite [7-10]. Wei et al. [10] consider a metastable nature related to the martensitic structure even as the nitrogen amount is low; the " $\mathrm{m}$ " phase tends to form a BCC structure with distorted octahedral sites, which makes the accommodation of nitrogen atoms difficult.

The expanded austenite is a layer rich in nitrogen, obtained in austenitic stainless steels like the AISI 304 after nitriding in temperature of $500^{\circ} \mathrm{C}$. Structural analyses show that the modified layer is dominated by a cubic phase with a substantial expansion of the austenite lattice and in some cases a fine layer $(<0.1 \mu \mathrm{m})$ of $\mathrm{CrN}$ and $\alpha$-Fe precipitates at the surface. The lattice parameters show that the expanded austenite could be described by a special triclinic crystalline structure [14-18].

The hardening can also modify the diffusion kinetics of nitriding process and consequently the nitride layer formation, but few studies about it were realized until now. This work shows a study of nitriding kinetics processing applied to the stainless steels AISI 304 and AISI 316 when initially submitted to different grade in cold work plastic deformation [13-15].

\section{Materials and Methods}

The austenitic stainless steels have substantial work hardening after cold work processing. In the present study cold worked and heat treated steels sheets were utilized (AISI 304 with $1.0 \mathrm{~mm}$ thickness and AISI 316 with $1.5 \mathrm{~mm}$ thickness). The chemical composition is presented in Table 1.

2.1. Samples Deformation Process. Tensile test samples were prepared to induce cold plastic deformation by tensile test using a universal machine tensile test MTS810, by the ASTM E8MM-98 test procedure. The employed deformation degree in heat treated steels was $0 \%, 10 \%, 20 \%, 30 \%$, and $40 \%$ (Figure 1).

2.2. Nitriding Processes. The three possible nitriding processes were explored. Each tested sample was divided in four identical samples (Figure 2):

(i) Samples 01: for characterization of initial condition.

(ii) Samples 02: gaseous nitriding at $570^{\circ} \mathrm{C}$ during $3.5 \mathrm{~h}$.

(iii) Samples 03: plasma nitriding at $430^{\circ} \mathrm{C}$ during $10 \mathrm{~h}$.

(iv) Samples 04: liquid nitriding at $570^{\circ} \mathrm{C}$ during $2 \mathrm{~h}$.

2.3. Metallographic Preparation for Optical Microscopy. Metallographic samples were obtained by abrasive cutting. Samples (squares of $5 \mathrm{~mm}$ ) with and without the nitriding process were transversally sectioned with adequate "cutoff." The metallographic specimen mounting is done in a hot thermosetting powder mounting material (bakelite) and after this it was utilized the traditional steels metallographic 
TABLE 2: SEM parameters for the $\mathrm{N}$ and $\mathrm{C}$ analysis.

\begin{tabular}{lc}
\hline Work distance & $12.25 \mathrm{~mm}$ \\
"Spot size" of the beam & 7.5 \\
$\mathrm{kV}$ & 12 \\
Current density & $50 \mathrm{nA}$ \\
Exposition time & $20 \mathrm{~s}$ \\
\hline
\end{tabular}

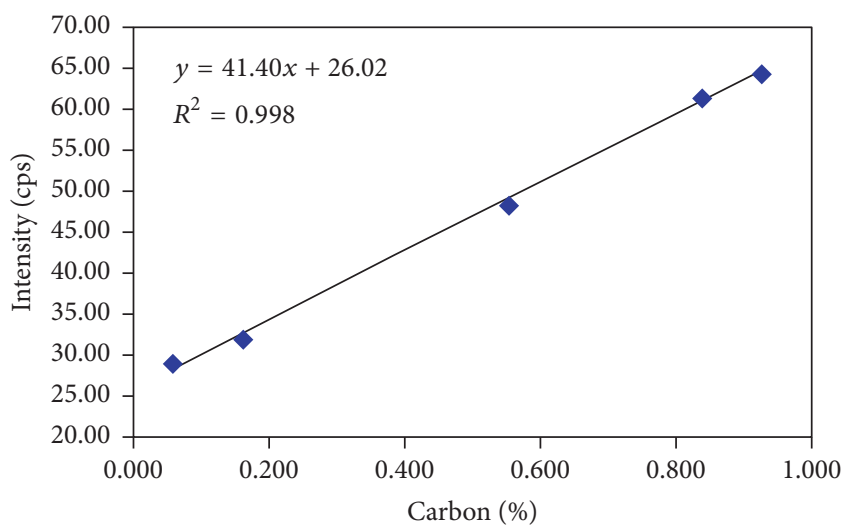

FIGURE 3: Calibration curve of carbon element.

preparation method (planar grinding, rough polishing, final polishing, and chemical etching).

2.4. Microstructural Analysis of the Samples. The final polished samples were etched with Marble's reagent for Leica optical microscope observation with image program A4iDocu capture, and the nitriding layer of the steels samples was measured and also documented.

For SEM observations, the samples were completely repolished, cleaned, and covered with a fine conductive $\mathrm{Al}$ layer. Through a WDS MICROSPEC analyzer in a SEM PHILIPS Quanta 600 the N and C elements were quantified.

The composition curves were determined for $\mathrm{N}$ and $\mathrm{C}$ elements from surface for the core direction with points spaced out to $5 \mu \mathrm{m}$. The nitrogen element was quantified automatically by the SEM, but the automatic method was not well succeeded for carbon.

The carbon calibration method was very effective with the SEM parameters (Table 2) and through five carbon steel patterns $(0.060 \%$ C; $0.163 \%$ C; $0.554 \%$ C, $0.838 \%$ C; $0.926 \%$ C) the X-ray peak curve of the carbon element was obtained (Figure 3).

Utilizing the expression $y=41.40 x+26.02$ (see Figure 3) it is possible to quantify the carbon element.

2.5. Vickers Hardness Measurements. For hardness measurements of the steel matrix and also the hardness profile related to the layer depth, Vickers hardness equipment with the following parameters was utilized: $10 a d=50 \mathrm{~g}$; load time $=$ $15 \mathrm{~s}$.

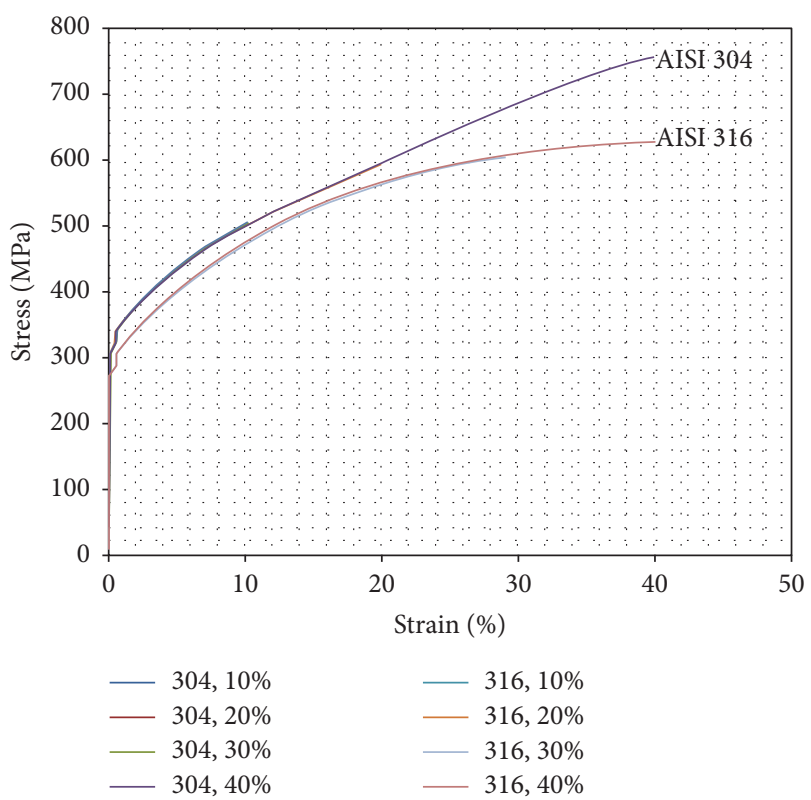

FIgURE 4: Stress-strain curves in deformed AISI 304 and 316 samples.

\section{Results and Discussion}

3.1. Mechanical Behavior. The tensile test curves of the samples are shown in Figure 4. Due to the low elastic (deformation) behavior of the samples, their results are not considered in this study.

Austenitic stainless steels are susceptible to induced martensite by cold plastic deformation that are strongly related to the alloy chemical composition, mainly the carbon content, due to its effect of the martensite transformation temperature lowering, reducing the possibility of the martensite induced by plastic cold deformation.

3.2. Optical Microscopy Characterization. Two sublayers inside the nitride area are observed in all samples (Figures 5 and 6).

There is a solid tendency to the occurrence of martensite during the plastic cold deformation, mainly in low carbon steels as 304L [18]. In conditions where the steels were acquired, an enough defect concentration to evaluate this influence in the kinetics study of the nitrogen diffusion during the nitriding processes is expected.

Moreover, the thickness variations were random (Table 3) and do not suggest any tendency relating to the influence in thickness due to employed cold plastic deformation degree.

Concerning Figure 6, an example of optical micrographs referring to AISI 316 and AISI 304 nitriding process is shown. In all studied conditions the thicknesses of nitride layer was measured.

3.3. Chemical Analysis by WDS (Scanning Electron Microscopy). The nitrogen and carbon concentration, illustrated in Figure 7 , obtained by wave dispersive $\mathrm{X}$-rays spectrometry 


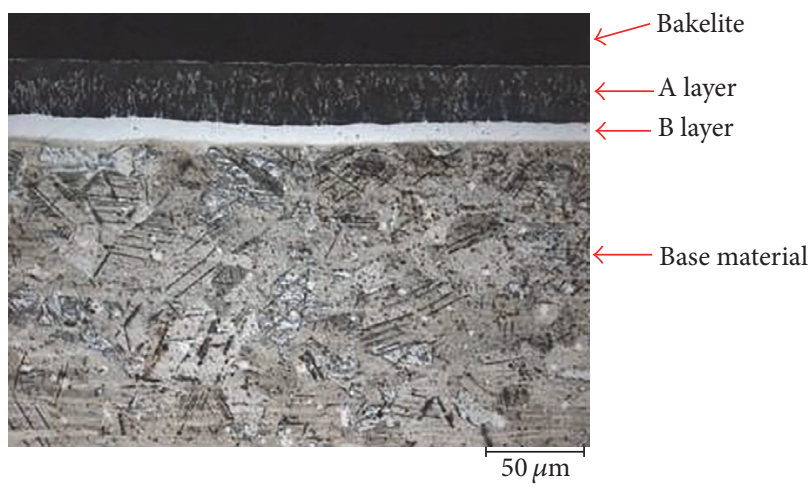

FIGURE 5: General reference example for the nitride layer thickness measurements (plasma nitriding process in AISI 316 stainless steel).

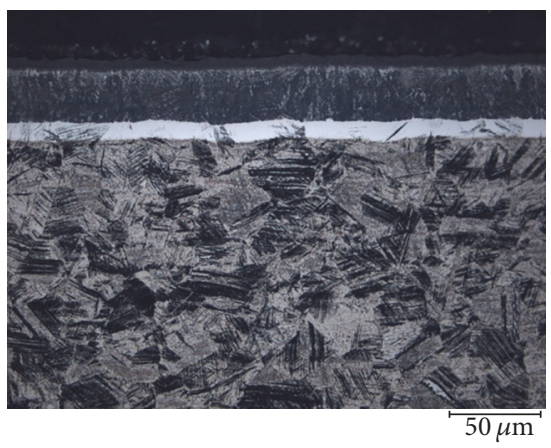

(a)

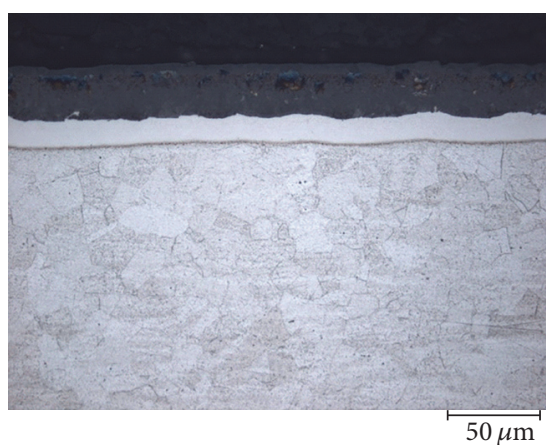

(d)

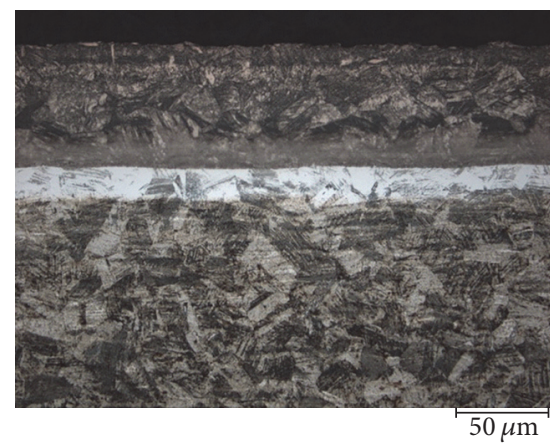

(b)

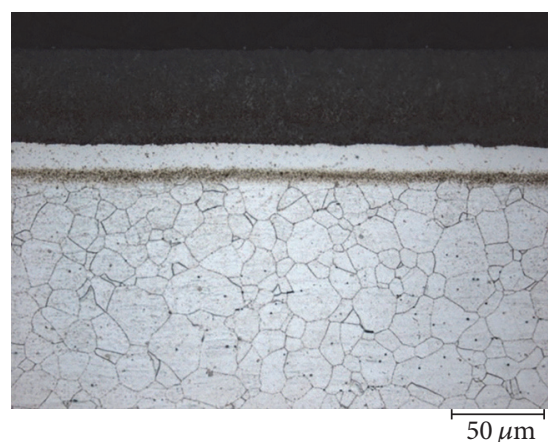

(e)

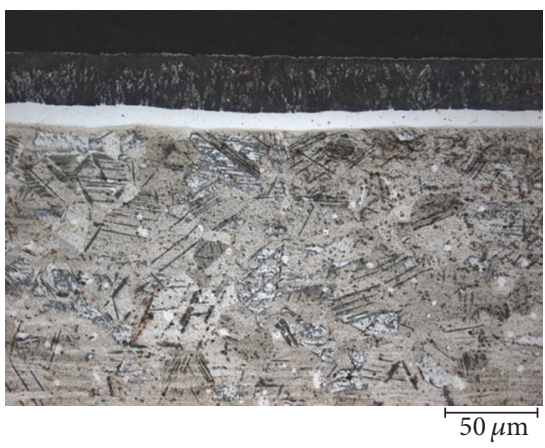

(c)

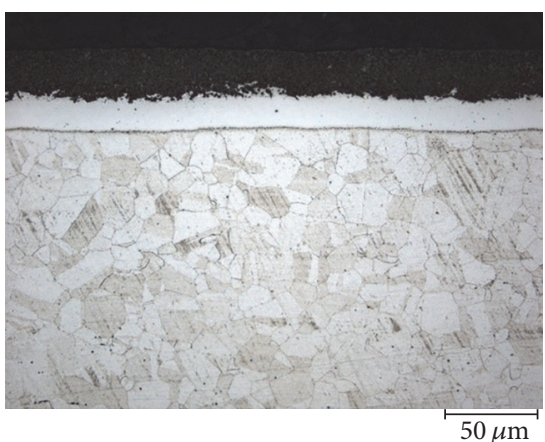

(f)

Figure 6: AISI 316 (a) liquid nitriding process; (b) gaseous nitriding process; (c) plasma nitriding process. AISI 304 (a) liquid nitriding process; (b) gaseous nitriding process; (c) plasma nitriding (marble etching) (figure bar scale equal to $50 \mu \mathrm{m}$ ).

(WDS) using SEM can be observed, where the first layer has a nitrogen concentration of $5.5 \%$ and the second layer shows a $1 \%$ carbon concentration peak. Both steels can have up to 0.08 weight $\%$ of carbon and, with the exception of the liquid nitriding process, the gaseous and plasma processes are free of carbon. Then it can be concluded that in this region a decarbonization with nitrogen diffusion possibly occurs and these carbon atoms are diffusing to regions just below the real nitride layer, forming a second layer with a superior carbon concentration. Consequently two layers originate, the first a matrix of austenite expanded by nitrogen atoms, followed by another layer formed by matrix of austenite expanded by carbon atoms.

3.4. Microhardness Analysis. Figure 8 shows the hardness value of the samples with different degree of cold work before nitriding processes. There is a considerable hardness increase, more with the AISI 304 steel, possibly due to the strong tendency for the occurrence of martensite induced by plastic cold work. 
TABLE 3: Average thickness of the nitride layer $(\mu \mathrm{m})$ relating to Figure 5.

\begin{tabular}{|c|c|c|c|c|c|c|c|}
\hline \multirow[b]{2}{*}{ AISI } & \multirow[b]{2}{*}{ Deformations } & \multicolumn{3}{|c|}{ A layer } & \multicolumn{3}{|c|}{ B layer } \\
\hline & & Gaseous & Plasma & Liquid & Gaseous & Plasma & Liquid \\
\hline \multirow{5}{*}{304} & $0 \%$ & 71 & 33 & 34 & 16 & 10 & 10 \\
\hline & $10 \%$ & 67 & 29 & 33 & 15 & 13 & 10 \\
\hline & $20 \%$ & 65 & 34 & 33 & 13 & 9 & 10 \\
\hline & $30 \%$ & 66 & 26 & 32 & 17 & 11 & 10 \\
\hline & $40 \%$ & 71 & 26 & 33 & 18 & 12 & 10 \\
\hline \multirow{5}{*}{316} & $0 \%$ & 51 & 29 & 28 & 12 & 17 & 11 \\
\hline & $10 \%$ & 48 & 20 & 23 & 12 & 18 & 10 \\
\hline & $20 \%$ & 50 & 27 & 22 & 15 & 13 & 9 \\
\hline & $30 \%$ & 47 & 28 & 24 & 15 & 17 & 10 \\
\hline & $40 \%$ & 51 & 20 & 26 & 14 & 18 & 10 \\
\hline
\end{tabular}

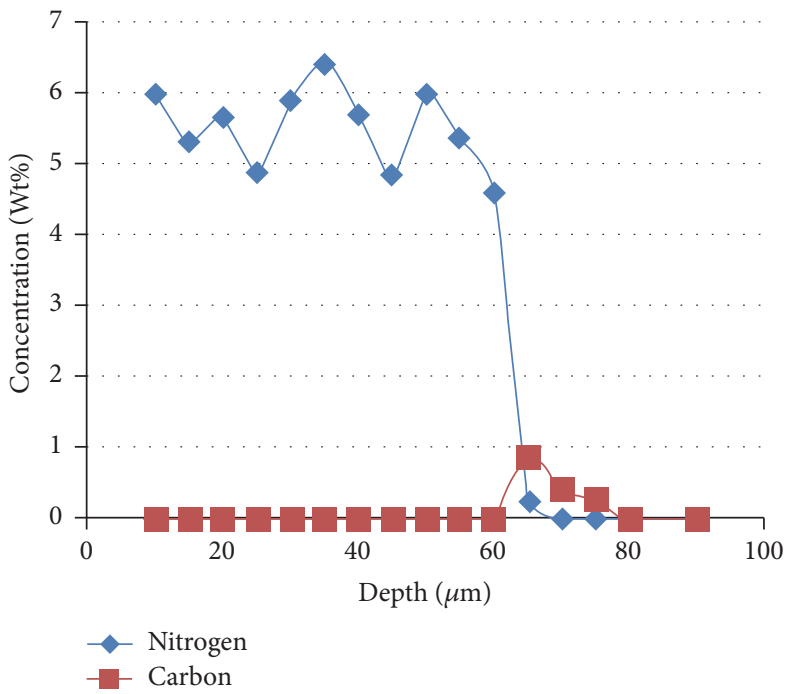

(a)

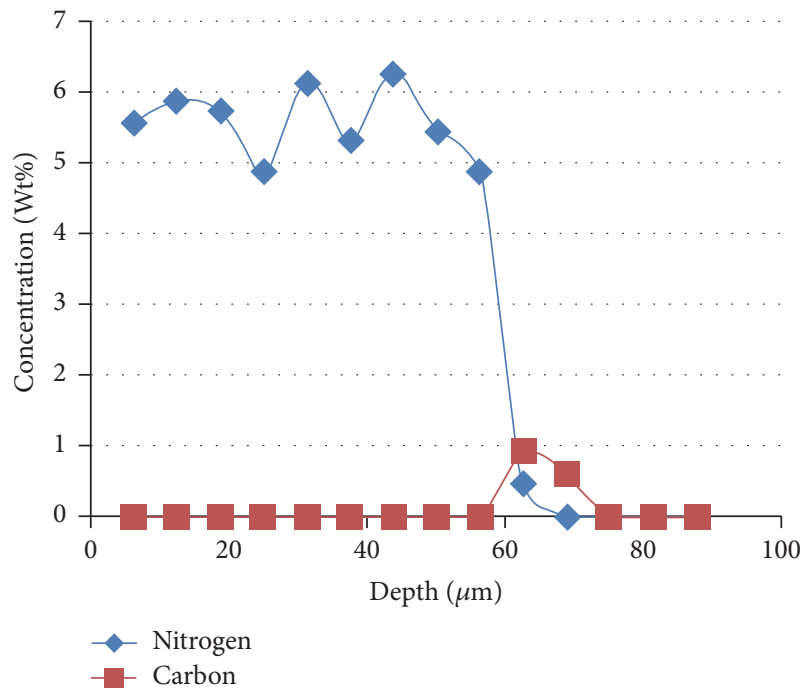

(b)

FIgURE 7: Nitrogen and carbon distribution (weight\%) regarding the layer depth in (a) AISI 304 steel and (b) AISI 316 steel.

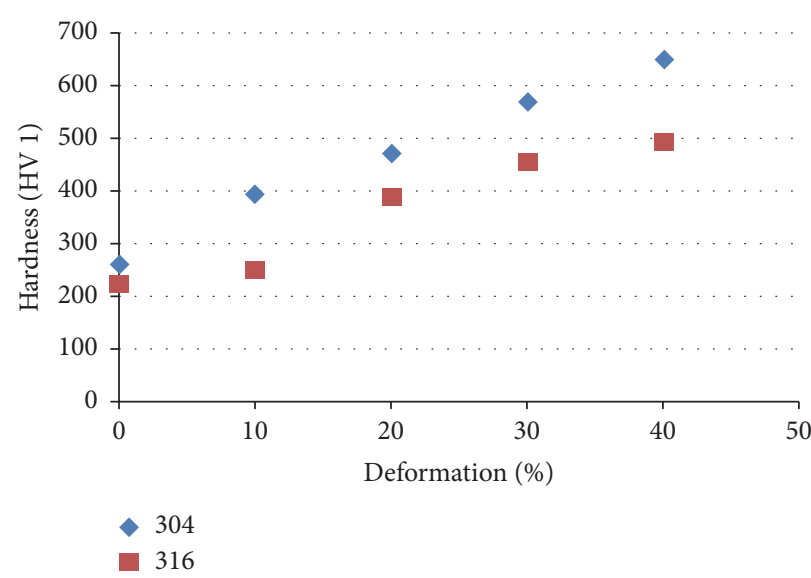

FIGURE 8: Hardness values of the cold work samples of AISI 304 and 306 steels. 

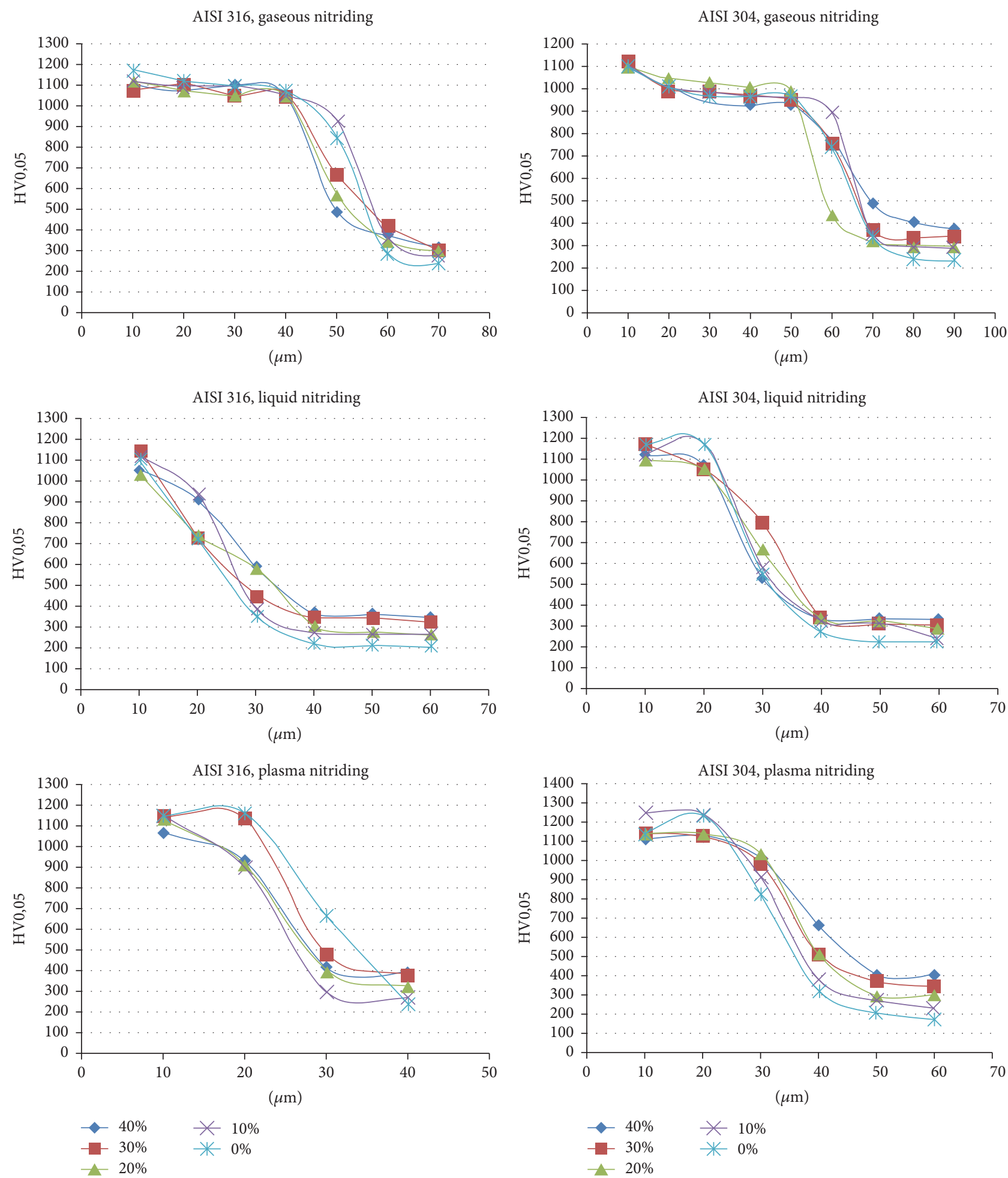

FIGURE 9: Hardness curves in samples after diverse nitriding processes.

Figure 9 shows the hardness curves of the samples after nitriding process; it can be observed, with the data, that the applied precold work shows a little influence in all the utilized diffusion processes.
Concerning that both AISI 304 and 316 were nitrated in same conditions, more high hardness values in AISI 304 samples depth are observed. Besides, higher values were obtained in samples with plasma nitriding processes, 
probably due to the applied process temperature (plasma, $T$ $=430^{\circ} \mathrm{C}$; gaseous and liquid, $T=570^{\circ} \mathrm{C}$ )

\section{Conclusions}

The initial cold work (hardening) in both AISI 304 and 306 austenitic stainless steels does not show special influence in all applied nitriding kinetics. In both studied materials two distinguished layers are observed in the microstructure, one formed by the austenite expanded due to the presence of nitrogen atoms followed by another layer formed by austenite expanded due to the presence of carbon atoms. The gaseous and liquid nitriding processes showed hardness values in the layers of $1100 \mathrm{HV}$ and the plasma nitriding process $1200 \mathrm{HV}$. Better diffusion kinetics occurrence in AISI 304 steel is also observed.

\section{Competing Interests}

The authors declare that they have no competing interests.

\section{Acknowledgments}

The authors would like to thank the Research Center of MAHLE Metal Leve (São Paulo, Brazil) for the utilization of laboratory equipment. Also they thank IPEN, UPM, and $\mathrm{CNPq}$ (Brazilian fellowship) for financial support.

\section{References}

[1] J. R. Davis, Ed., ASM Specialty Handbook: Stainless Steels, ASM, New York, NY, USA, 1994.

[2] W. Ozgowicz, E. Kalinowska-Ozgowicz, and A. Kurc, "Influence of plastic deformation on structure and mechanical properties of stainless steel type X5CrNi18-10," Journal of Achievements in Materials and Manufacturing Engineering, vol. 32, no. 1, pp. 3740, 2008.

[3] M. Blicharski and S. Gorczyca, "Structural inhomogeneity of deformed austenitic stainless steel," Metal Science, vol. 12, pp. 303-312, 1978.

[4] M. Milad, N. Zreiba, F. Elhalouani, and C. Baradai, "The effect of cold work on structure and properties of AISI 304 stainless steel," Journal of Materials Processing Technology, vol. 203, no. $1-3$, pp. 80-85, 2008.

[5] T. S. Byun, N. Hashimoto, and K. Farrell, "Temperature dependence of strain hardening and plastic instability behaviors in austenitic stainless steels," Acta Materialia, vol. 52, no. 13, pp. 3889-3899, 2004.

[6] R. B. Dailly and A. Hendry, "The effect of nitrogen on the mechanical behaviour of cold-worked austenitic stainless steel rod," in Proceedings of the 5th International Conference on High Nitrogen Steels (HNS-5 '98), vol. 318-320, pp. 427-436, Materials Science Forum, Espoo, Finland, May 1998.

[7] R. N. Bolster and I. L. Singer, "Surface hardness and abrasive wear resistance of nitrogen-implanted steels," Applied Physics Letters, vol. 36, no. 3, pp. 208-209, 1980.

[8] L. C. Gontijo, R. Machado, E. J. Miola, L. C. Casteletti, N. G. Alcântara, and P. A. P. Nascente, "Study of the S phase formed on plasma-nitrided AISI 316L stainless steel," Materials Science and Engineering: A, vol. 431, no. 1-2, pp. 315-321, 2006.
[9] M. Samandi, B. A. Shedden, D. I. Smith, G. A. Collins, R. Hutchings, and J. Tendys, "Microstructure, corrosion and tribological behaviour of plasma immersion ion-implanted austenitic stainless steel," Surface and Coatings Technology, vol. 59, no. 1-3, pp. 261-266, 1993.

[10] R. Wei, B. Shogrin, P. J. Wilbur et al., "Effects of low-energynitrogen-ion implantation on the tribological and microstructural characteristics of AISI 304 stainless steel," Journal of Tribology, vol. 116, no. 4, pp. 870-876, 1994.

[11] I. L. Singer, R. G. Vardiman, and R. N. Bolster, "Polishing wear resistance of ion-implanted 304 steel," Journal of Materials Research, vol. 3, no. 6, pp. 1134-1143, 1988.

[12] R. Wei, B. Shogrin, P. J. Wilbur et al., "The effects of low-energynitrogen-ion implantation on the tribological and microstructural characteristics of AISI 304 stainless steel," Journal of Tribology, vol. 116, no. 4, pp. 870-876, 1994.

[13] J. Piekoszewski, B. Sartowska, L. Waliś et al., "Interaction of nitrogen atoms in expanded austenite formed in pure iron by intense nitrogen plasma pulses," Nukleonika, vol. 49, no. 2, pp. 57-60, 2004.

[14] L. Pranevicius, C. Templier, J.-P. Rivière, P. Méheust, L. L. Pranevicius, and G. Abrasonis, "On the mechanism of ion nitriding of an austenitic stainless steel," Surface and Coatings Technology, vol. 135, no. 2-3, pp. 250-257, 2001.

[15] A. F. Padilha and P. R. Rios, "Decomposition of austenite in austenitic stainless steels," ISIJ International, vol. 42, no. 4, pp. 325-337, 2002.

[16] S. Picard, J. B. Memet, R. Sabot, J. L. Grosseau-Poussard, J. P. Rivière, and R. Meilland, "Corrosion behaviour, microhardness and surface characterisation of low energy, high current ion implanted austenitic stainless steel," Materials Science and Engineering: A, vol. 303, no. 1-2, pp. 163-172, 2001.

[17] L. C. Casteletti, A. Lombardi Neto, and G. E. Totten, "Plasma Nitriding of Stainless Steels," March 2008, http://www .industrialheating.com/articles/87861-plasma-nitriding-ofstainless-steels.

[18] J. Vatavuk, G. M. S. Lebrão, and A. Borro Jr., "A discussion concerning relevant aspects in austenitic stainless steel 304 series submitted to cold plastic deformation during manufacture," Revista Mackenzie de Engenharia e Computação.São Paulo, no. 2, 2001 (Portuguese). 

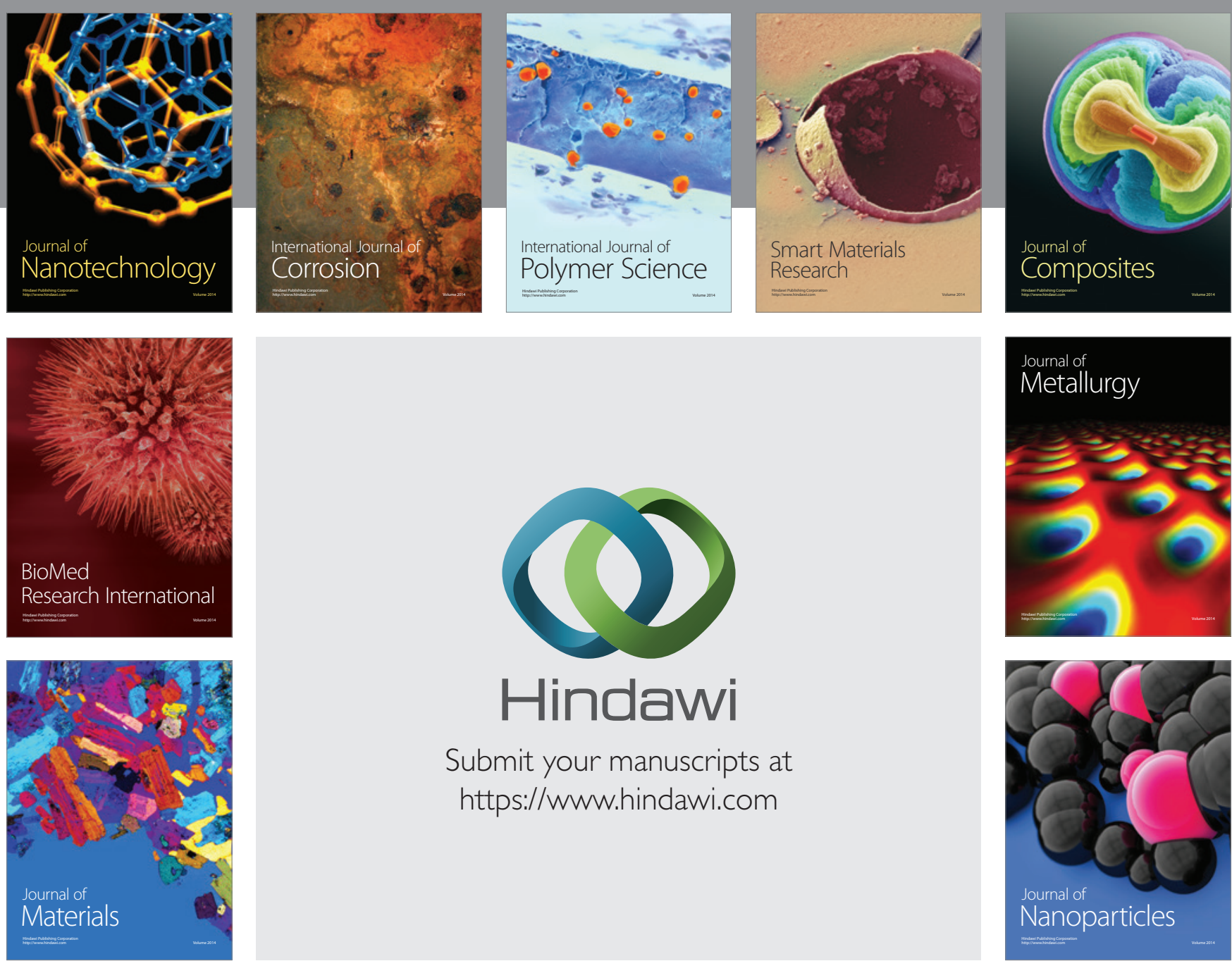

\section{Hindawi}

Submit your manuscripts at

https://www.hindawi.com

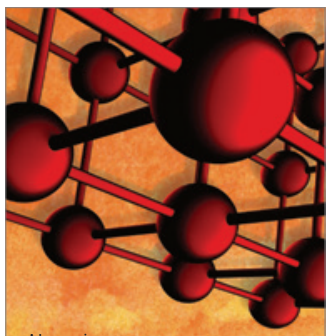

Materials Science and Engineering
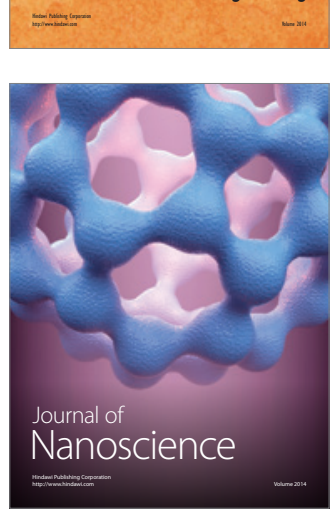
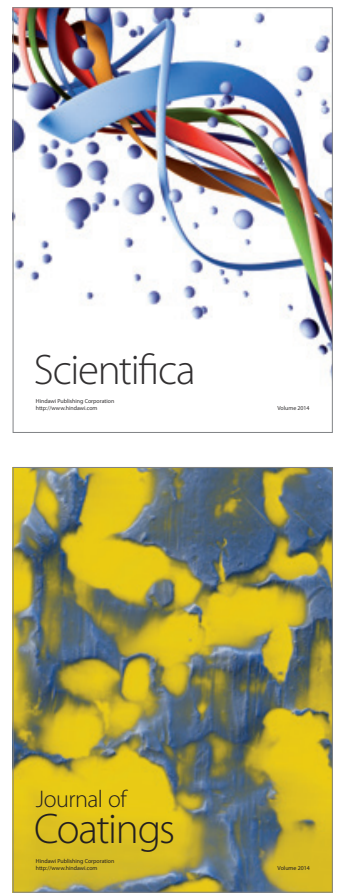
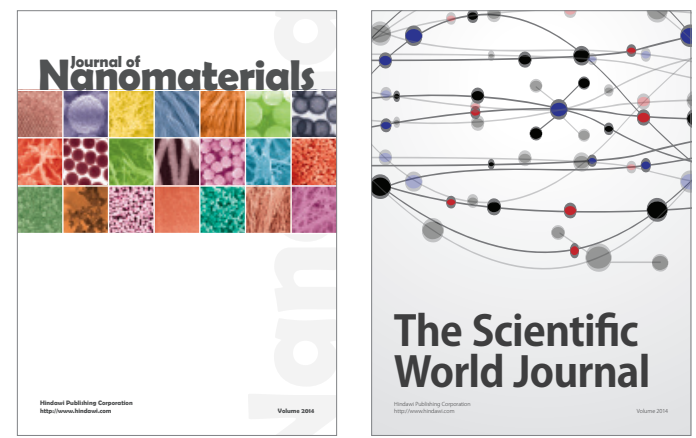

The Scientific World Journal
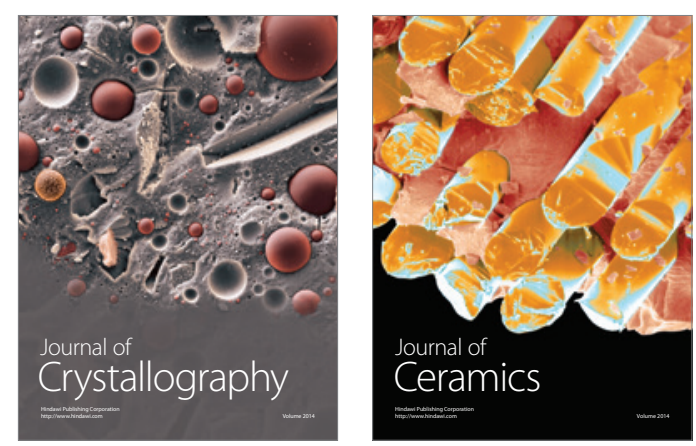
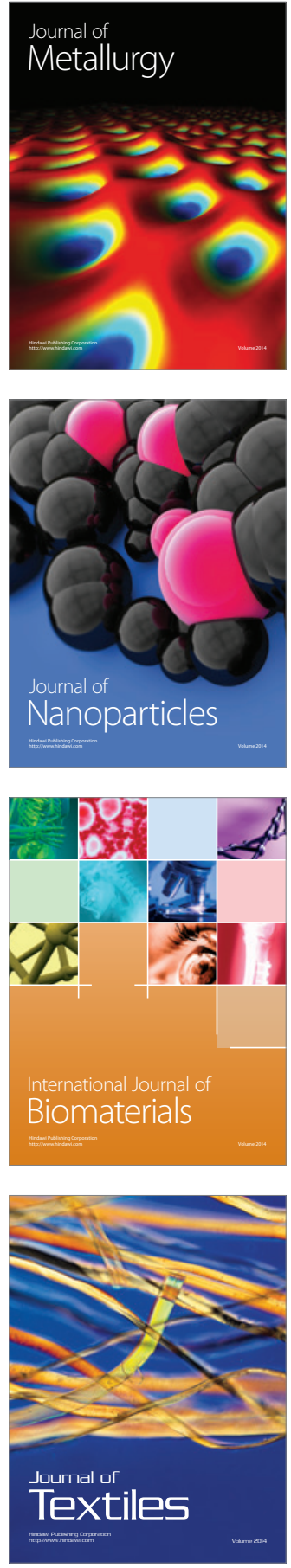